\title{
Autumn physical limnological experimental campaign in the Island Mainau littoral zone of Lake Constance
}

\author{
Irina CHUBARENKO*, Boris CHUBARENKO, Erich BÄUERLE ${ }^{1)}$, Yongqi WANG ${ }^{2}$ and Kolumban HUTTER ${ }^{2)}$ \\ Atlantic Branch of P.P. Shirshov Institute of Oceanology, Russian Academy of Sciences, 236000 Prospect Mira 1, Kaliningrad, Russia \\ ${ }^{1)}$ Limnologisches Institut, Universität Konstanz, 78457 Konstanz, Deutschland \\ ${ }^{2)}$ Institut für Mechanik, Technische Universität Darmstadt, Hochschulstr. 1, 64289 Darmstadt, Deutschland \\ *e-mail corresponding author: irina@ioran.gazinter.net
}

\begin{abstract}
From October $12^{\text {th }}$ to November $19^{\text {th }} 2001$ a hydrophysical field measurement campaign was carried out in the littoral zone of Lake Überlingen and the Upper Lake Constance around the Island Mainau and in the adjacent aquatic area. Measurements involved (i) deployment of current-meters, thermistors and thermistor-chains at fixed positions, (ii) CTD-towing with the boat in the subsurface layer, (iii) CTD profiling at selected positions and deployment of drifters at selected depths and positions around the Island Mainau. The measurements that were conducted are described and illustrated by typical plots. The data as well as closer description of the campaign are public domain and can be downloaded for use through Internet.
\end{abstract}

Key words: physical limnology, measurements, littoral, near-coast island, Lake Constance

\section{INTRODUCTION}

The Limnological Institute of the University of Constance together with the limnology unit of the Darmstadt University of Technology, both through funds from the Deutsche Forschungsgemeinschaft, conducted from October $12^{\text {th }}$ to November $19^{\text {th }} 2001$ a hydrophysical field measurement campaign in the littoral zone around the Island Mainau and in Lake Überlingen, the western arm of the Upper Lake Constance (Fig. 1). The intention was to gain a deeper understanding of the local spatial and temporal distribution of the temperature and the water currents in this littoral zone and to possibly obtain an information how this behaviour might be connected to the processes in the pelagial zone.

The field campaign was conducted as part of a larger concentrated effort in which a holistic record of the entire Upper Lake Constance was taken. The Institut für Wasserbau, University of Stuttgart (Prof. H. Kobus), the Centre for Water Research, University of Western Australia, Perth (Prof. J. Imberger), the Physical Limnology group of Eidg. Anstalt für Wasserversorgung, Abwasserreinigung und Gewässerschutz in Kastanienbaum, Switzerland (Dr. A. Lorke), the remote sensing group of the Deutsches Zentrum für Luft und Raumfahrt (DLR), Oberpfaffenhofen, the Umwelt-Forschungszentrum Leipzig-Halle (Dr. B. Böhrer) and the Institut für Seenforschung, Landesamt für Umwelt, Baden-Württemberg in Langenargen simultaneously deployed their instruments in different parts all over the lake.

Our own measurements involved (i) deployment of current-meters, thermistors and thermistor-chains at fixed positions, (ii) CTD-towing with the boat, (iii) CTD profiling at selected positions and deployment of drifters at selected depths and positions around the Island Mainau.

This brief note intends to alert the readers to the availability of the data. Via the Internet address http: //wegener.mechanik.tu-darmstadt.de/ag3 (menu item "Publications") a first description of the conducted measurements and possible interpretation of data is given. The same Internet address provides also a link to the electronic ASCII files of all the data, which are public domain.

\section{STUDY AREA, EXTERNAL CONDITIONS}

The study area is shown in figure 1 . It presents the stretch of Lake Überlingen with the Island Mainau on the SW shore and Unteruhldingen on the NE shore; the inset map shows the area as situated in Lake Constance. The isolines of the bathymetry show steep shores on both sides down to $150 \mathrm{~m}$ depth. The vicinity of the Island Mainau in the Obere and the Untere Güll is very shallow, in large parts less than $5 \mathrm{~m}$, and the bypass connecting the Obere and Untere Güll is only 1-2 m deep and app. $100 \mathrm{~m}$ wide. A distinctive feature is the Mainau sill, north of the island, where the talweg of the lake rises to $100 \mathrm{~m}$ depth; it is flanked on both sides by the steep shore at Litzelstetten and Seefelden.

The meteorological situation during the measurement campaign was characterised by generally warm and calm weather prior to November, 1. Tails of warm fronts crossed the Constance region five times and led to NE, NW and WSW wind episodes with at most 5-7 m $\mathrm{s}^{-1}$ wind speed, lasting no longer than 5-10 hours. In November, a significant wind intensification occurred with 10-12 $\mathrm{m} \mathrm{s}^{-1}$ wind-speed, and from 6-9 November a long lasting steady wind was blowing from $\mathrm{W}$ which 
turned to NE on 10-12 November and favoured a considerable internal overall wave dynamics, that was basically absent prior to November, 6 .

The overall water balance of the lake was negative, with a decreasing water level of about $40 \mathrm{~cm}$ during 25 days.

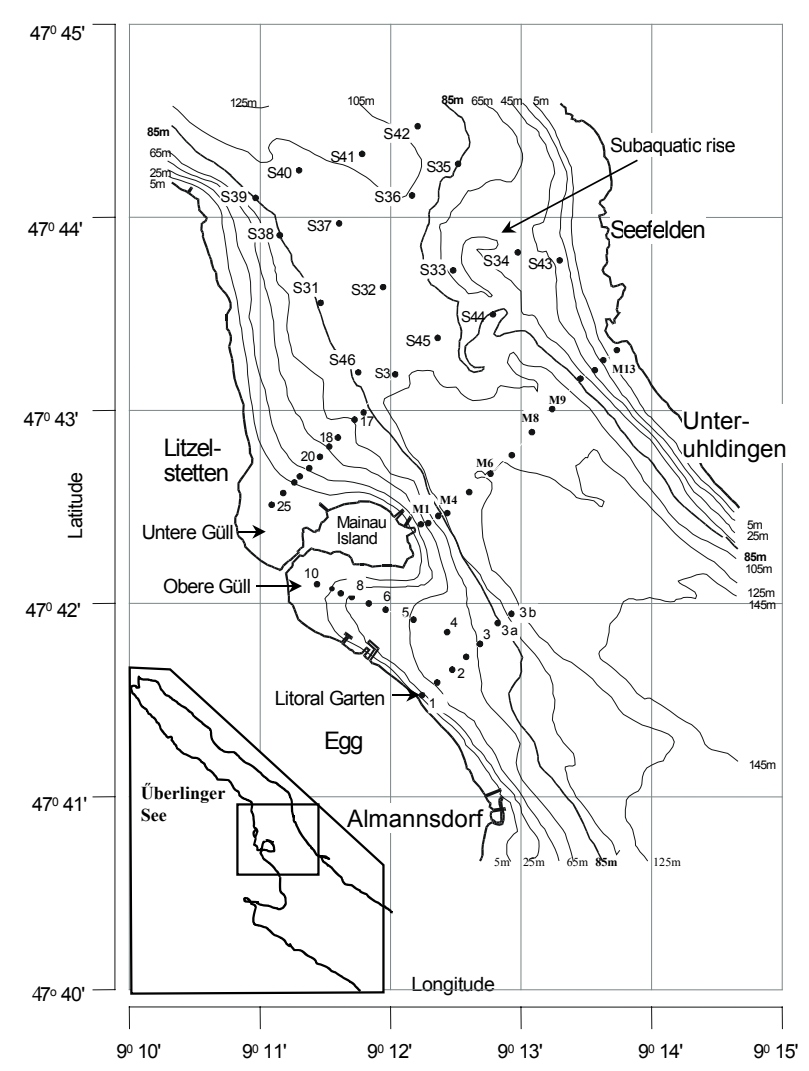

Fig. 1. Region in Lake Überlingen where CTD profile measurements were made between 19 October and 12 November 2001: (i) in the vicinity of the Island Mainau, (ii) on the Unteruhldingen subaquatic rise and (iii) in the "Litoral Garten" measurements site. The measuring points lie on lines approximately in the direction of steepest descent of the bathymetric profile (Untere and Obere Güll, "Litoral Garten"), across the Lake (along a line Mainau - Unteruhldingen) and in a near-square area above the Mainau sill and above the subaquatic rise at Unteruhldingen. The inset map shows the area within Lake Überlingen.

The vertical temperature structure (Fig. 2) in the lake reflected the external calm wind situation in October and its sudden change in early November. Temperature profiles in October show a large surface temperature $\left(\sim 15^{\circ} \mathrm{C}\right)$, a relatively thin mixed layer of approximately $6 \mathrm{~m}$ of thickness and a slow continuous transition to the hypolimnion with a temperature of approximately 5.5 ${ }^{\circ} \mathrm{C}$. To the end of October, air temperature dropped stably on the temperature of water surface. In the night from October $31^{\text {st }}$ to November $1^{\text {st }}$ the relatively strong wind introduced more turbulence, the upper mixed layer temperature dropped to $12.6^{\circ} \mathrm{C}$ and its thickness increased to about $13 \mathrm{~m}$ while the transition to the hypolimnion temperature of $5.5{ }^{\circ} \mathrm{C}$ was smoothed. A relative raise of hypolimnion water observed from October $12^{\text {th }}$, until November $5^{\text {th }}$, shown in the graphs on figure 2 , most likely is driven by internal wave dynamics at the time of measurement.

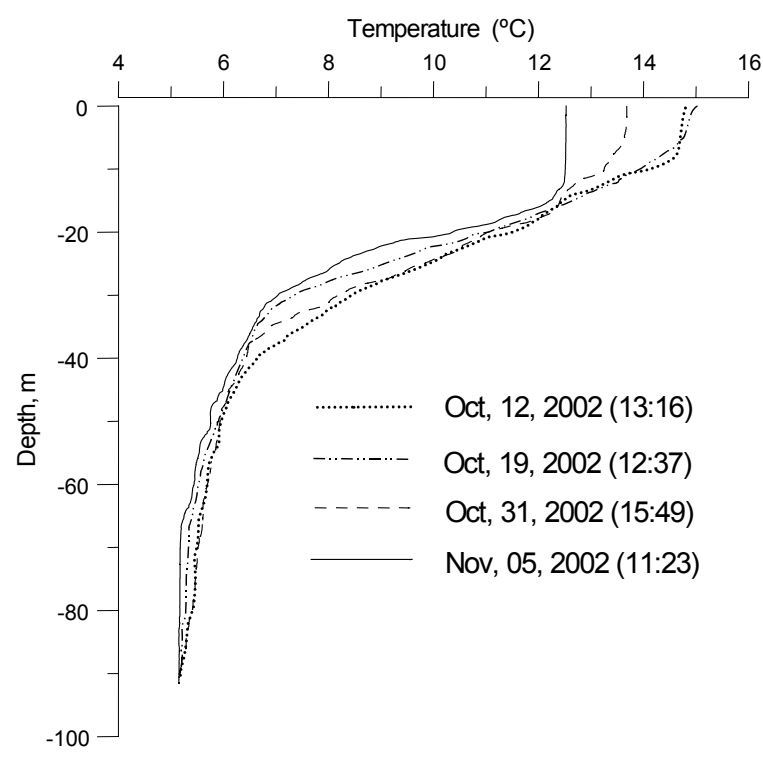

Fig. 2. Evolution of the vertical temperature distribution at position off the Island Mainau at the talweg during the measuring period between October $12^{\text {th }}$ and November $19^{\text {th }} 2001$. A significant cooling of $2.5^{\circ} \mathrm{C}$ in the surface layer is seen paired with an increase of the mixed layer depth due to turbulent mixing.

\section{MEASUREMENTS}

Water temperature and currents were measured (i) in the vicinity of the Island Mainau, (ii) the Unteruhldingen subaquatic rise and (iii) in the Littoral Garden of the Limnological Institute of the University of Constance.

\subsection{CTD measurements}

These were conducted with two different probes (OCEAN SEVEN 316; SIS CTD plus 500) that were calibrated against one another by joint repetitive measurements in one point of the lake, showing identical results. The technical accuracy of their temperature sensors is $0.003{ }^{\circ} \mathrm{C}$ with a resolution of $0.0005{ }^{\circ} \mathrm{C}$; this is well below the natural small-scale variability due to the turbulent patchiness in the temperature field that was observed to be about $0.01{ }^{\circ} \mathrm{C}$ during the inter-calibration experiment.

Vertical profiling with the CTD probe was conducted at the positions as indicated in figure 1. Two transects from the Obere and Untere Güll traversing approximately along the direction of the steepest descent of the bathymetry to $100 \mathrm{~m}$ depth, a transect from the Littoral Garden abeam the shoreline also to the depth of $100 \mathrm{~m}$ and across Lake Überlingen from the far-shore 
a) Conductivity $(\mathrm{mS} / \mathrm{cm})$

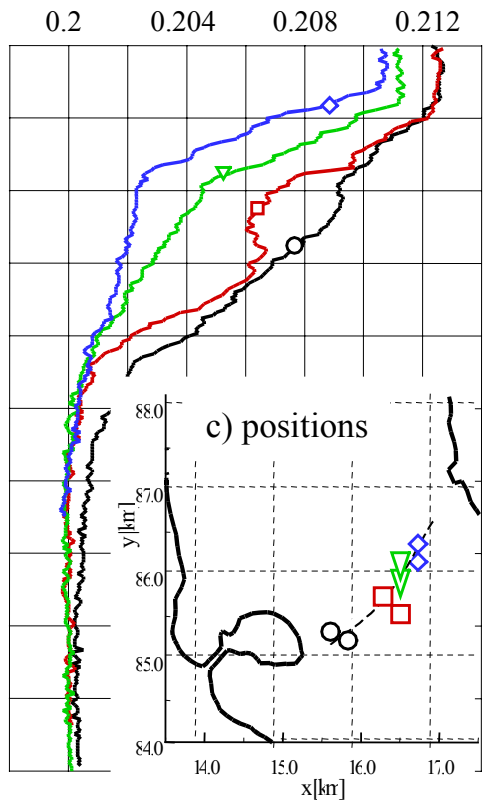

\section{b) Temperature $\left({ }^{\circ} \mathrm{C}\right)$}

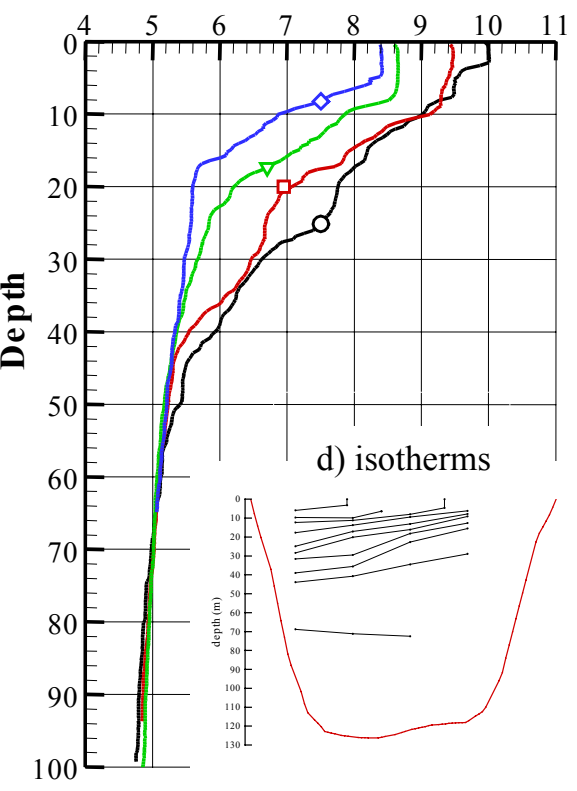

Fig. 3. Vertical conductivity and temperature profiles $(a, b)$ at four stations on the cross section from the Island Mainau to UnterUhldingen. c) Positions are taken at the beginning and the end of profiling. The profiles evidence a considerable across-lake horizontal gradient of the stratification, as shown in the isopleths of panel d).
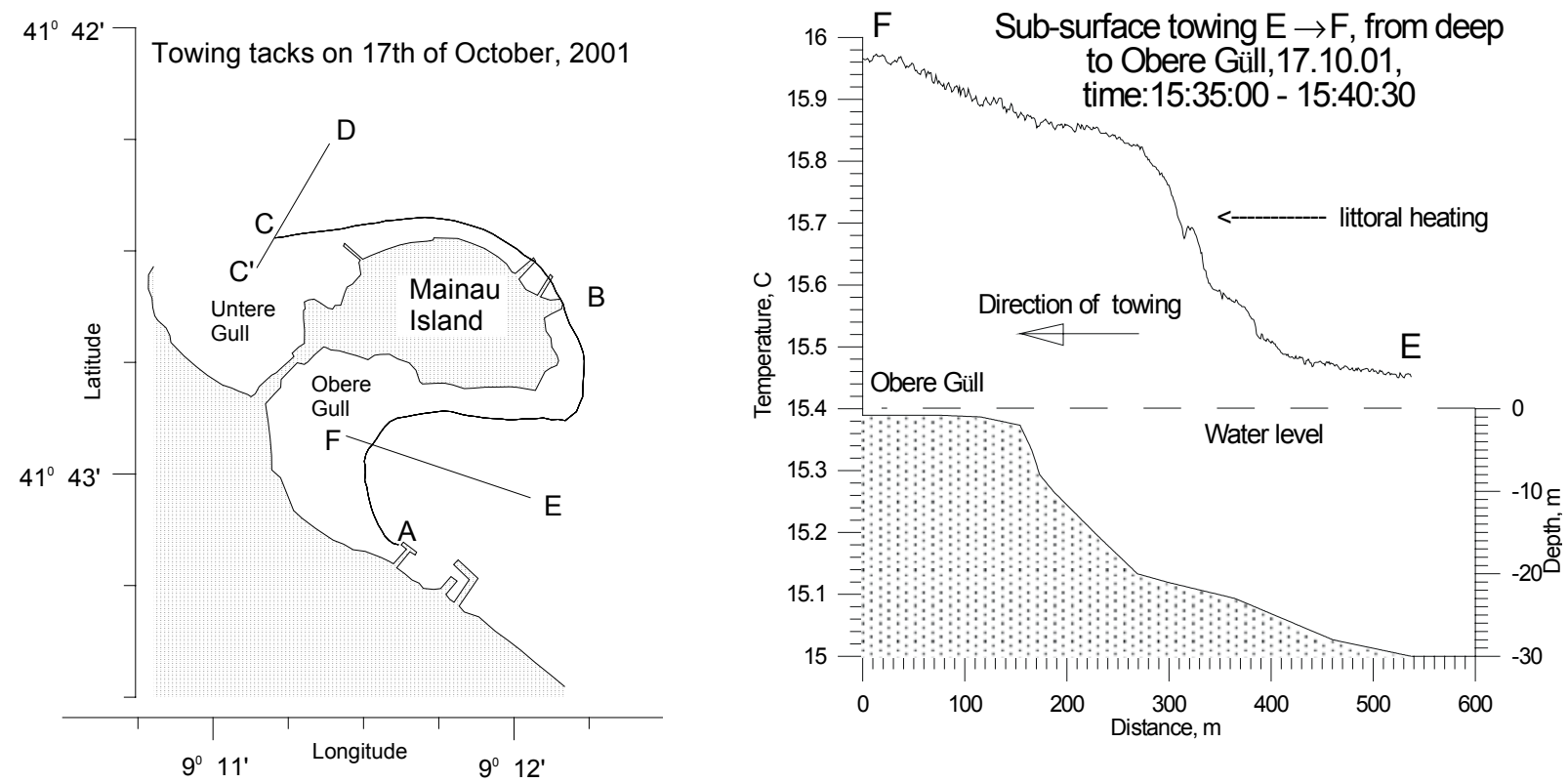

Fig. 4. Temperature transects at app. $10 \mathrm{~cm}$ depth, taken on October $17^{\text {th }} 2001$. Left panel: map of tacks in the Obere and Untere Güll and around the Island Mainau, and temperature variation along the transects $\mathrm{F} \rightarrow \mathrm{E}$ (right panel). Note the differential heating in the Obere Güll by appr. $0.5^{\circ} \mathrm{C}$.

end of the Island Mainau to Unteruhldingen on the opposite side of the lake. The measuring time for a transect was approximately 30-40 minutes, sufficiently short that on time scales of long internal waves (with periods of several hours) the thermal state of the lake could be regarded as quasi-stationary. The electrical conductivity and temperature profiles display occasion- ally a surprising structure (see Fig. 3 and its figure caption) suggesting considerable horizontal gradients.

A polygon survey, in which CTD profiles were taken on October $31^{\text {st }}$ at 16 points in an approximately quadratic area above and west of the subaquatic rise at Unteruhldingen situated immediately above the Mainau sill. The time was coincidental with the overall inflow 

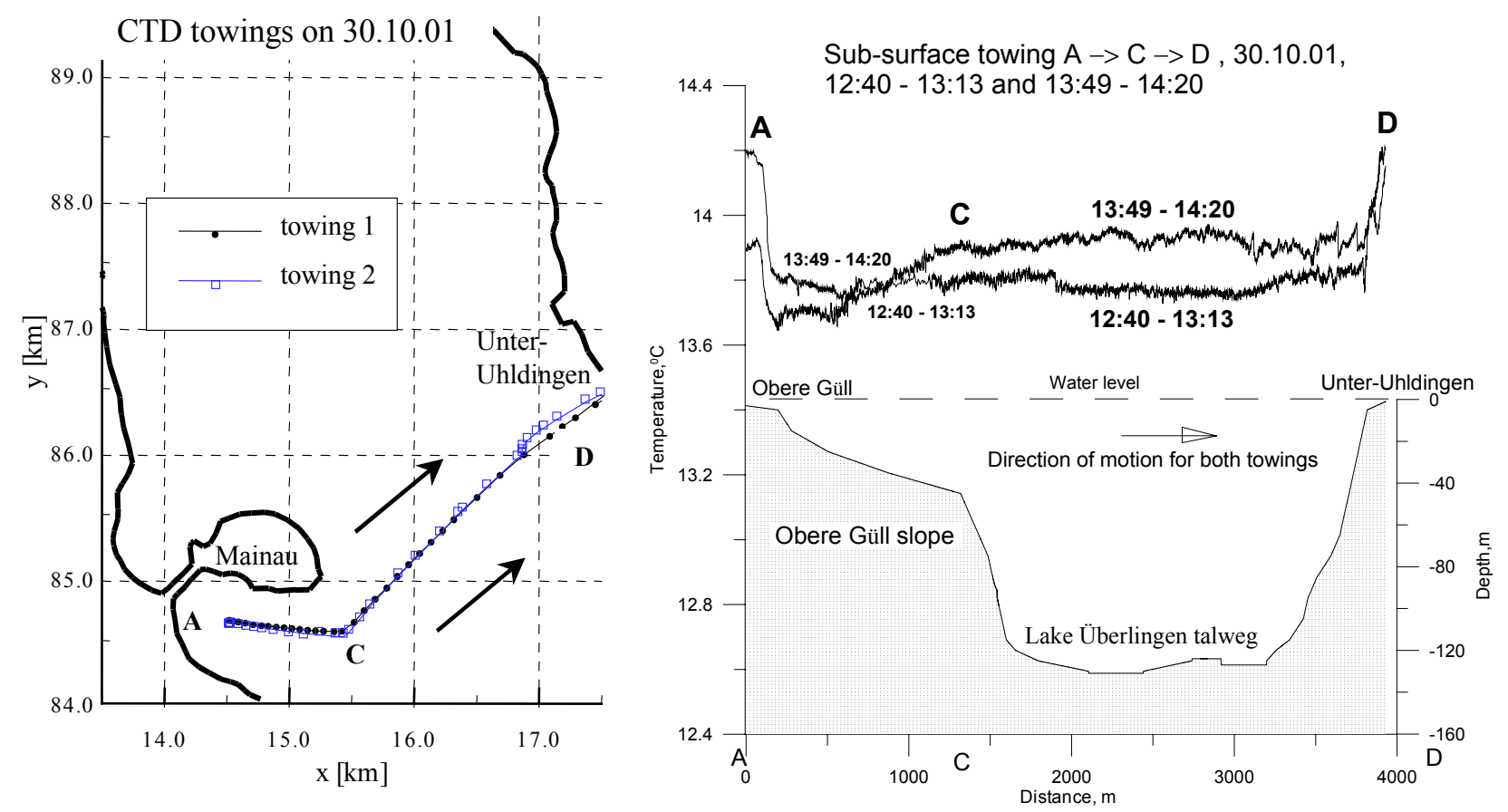

Fig. 5. Temperature transect at $5-10 \mathrm{~cm}$ below the surface across the lake from the Untere Güll to Unteruhldingen along A-C-H (left panel). The two temperature transects were taken, both from $\mathrm{A} \rightarrow \mathrm{D}$, with a time lapse of about $1 \mathrm{~h}$, on October $30^{\text {th }} 2001$. An approximate temperature increase up to $0.3^{\circ} \mathrm{C}$ can be observed.

of bottom water from the main basin of the Upper Lake Constance to Lake Überlingen and thus may provide information about the local thermal structure due to such an inflow.

Subsurface CTD-towings were extensively conducted during the entire measurement campaign and aimed at obtaining information on the small scale structure and variation of the temperature field in the horizontal direction and, in particular, with a view to the daily absorption differences of the solar irradiation in the pelagial and littoral zones around the Island Mainau. Subsurface temperatures, approximately $10 \mathrm{~cm}$ below the surface, are seen to depend on the variations of the bathymetry. Figure 4 indicates that the littoral region in the Obere Güll is warmer by approximately $0.5^{\circ} \mathrm{C}$ than the surface waters offshore at larger water depths. Furthermore, from towings across the lake from the Obere Güll to Unteruhldingen, performed on 30 October at about noon time with an hour difference (see Fig. 5), gives information on immediate surface heating by solar radiation. As seen in figure 5 the direct midday solar irradiation (that persisted at that day) resulted in one hour in a temperature rise of approximately $0.5^{\circ} \mathrm{C}$.

\subsection{Drifters}

Observations with drifters were carried out nearly daily. The intention was to see how local near shore current behaviour would affect the littoral zone. The meas- urements provide information about (i) the inflow/outflow peculiarities from Lake Überlingen into the main basin of the Upper Lake Constance, (ii) the general current structure around the Island Mainau and in the pelagial zone abeam of the island. Single drifters as well as clusters of drifters were followed with both, drifters set near the surface $(1-10 \mathrm{~m})$ and in the deep water $(65-105 \mathrm{~m})$. Their positions were determined with GPS by following them with a small boat and recording times and geographical co-ordinates.

\subsection{Measurements by stationary instruments}

Measurements site "Litoral garten". Three VEMCO thermistors were fixed at cages which were placed at the bottom of the "Litoral Garten" (Fig. 1) at 3.5, 7.5 and 15 $\mathrm{m}$ below Mean-Normal-Water-level (MNW), recording the water temperature $15 \mathrm{~cm}$ above the bottom at $5 \mathrm{~min}$ ute intervals. In addition, a thermistor chain was positioned at a location in the "Litoral Garten" with $23 \mathrm{~m}$ depth and in line with the other thermistors abeam the shore line. Temperatures were recorded at 5-min intervals every $2 \mathrm{~m}$ beginning $1.5 \mathrm{~m}$ above the bottom. Typical isotherm-depth-time series are shown in figure 6 .

Mainau sill and subaquatic bottom rise near Unteruhldingen. Two Aanderaa current meters were deployed at the saddle point (MM) of the Mainau sill, however the lower instrument failed to record any data. The second instrument, $31 \mathrm{~m}$ below the MNW-level, 


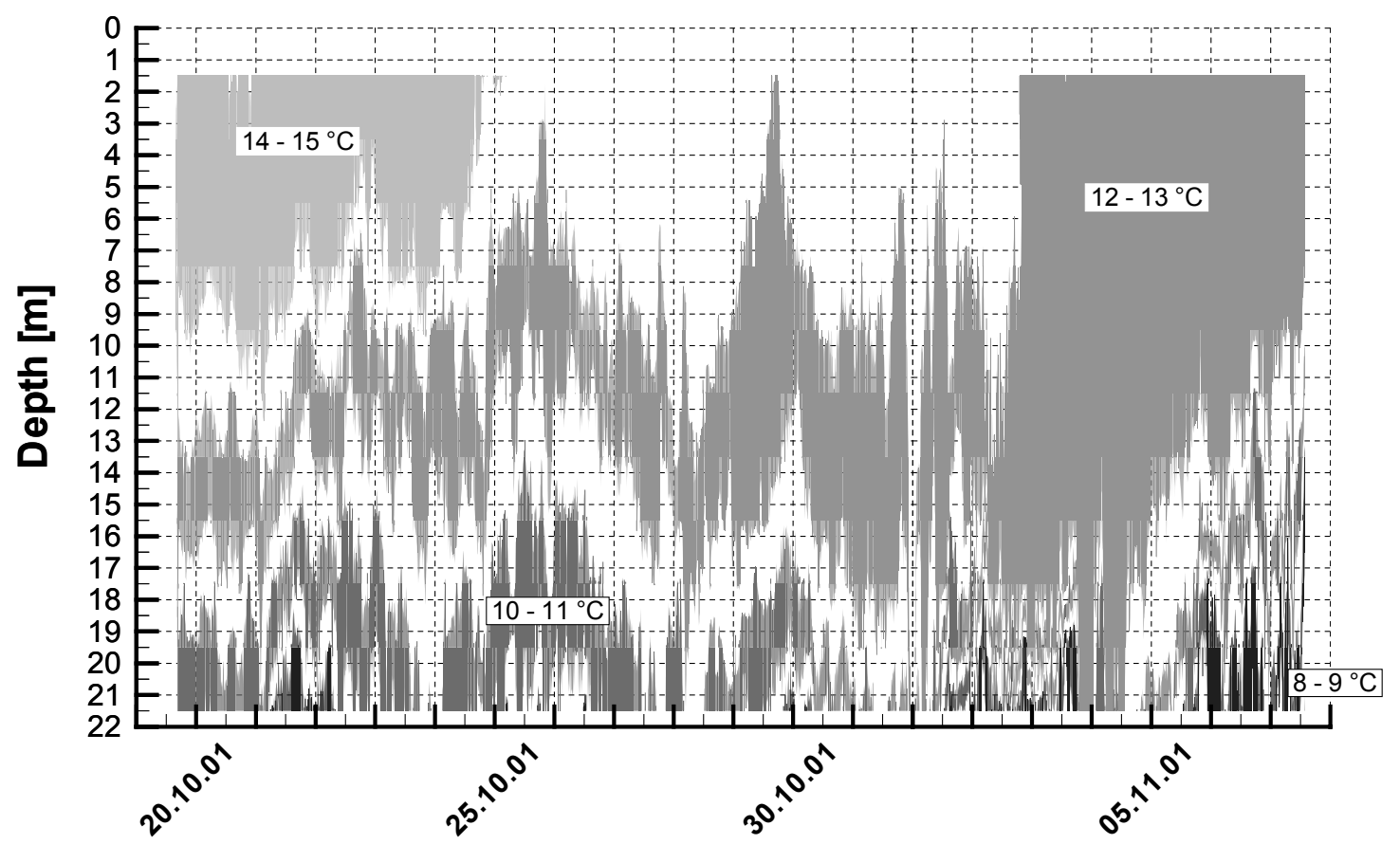

Fig. 6. Isotherm depth time series recorded in the "Litoral Garten" at the thermistor chain position between $1.5 \mathrm{~m}$ and $21.5 \mathrm{~m}$ below the MNW-level.

was positioned at the approximate thermocline depth, not adequate for measuring possible horizontal baroclinic currents. As a result, during the calm October period the current speeds were almost exclusively below the threshold of the Aanderaa current meters $(1.2 \mathrm{~cm}$ $\mathrm{s}^{-1}$ ). However, current directions were recorded and provide partially valuable information, i.e., they disclose conspicuous fluctuations with $8 \mathrm{~h}$ and $12 \mathrm{~h}$ periods.

\section{CONCLUSION}

A detailed report on many of the measured CTD, current and drifter data is available in the web under the

Received: January 2003

Accepted: February 2003 address http://wegener.mechanik.tu-darmstadt.de/ag3. This report also contains first interpretations. All measurements are furthermore collected in data files in ASCII-format with all necessary meta data, which are enclosed to the corresponding parts of the report.

\section{ACKNOWLEDGMENT}

This work has been supported by the Deutsche Forschungsgemeinschaft through the SFB 454 Bodenseelitoral and $\mathrm{Hu} 412 / 27-1$. 